\title{
Urban Housing Experience and Gender: An Empirical Study in Ibadan, Nigeria
}

\author{
Raimi A. Asiyanbola ${ }^{1}$ \\ ${ }^{1}$ Olabisi Onabanjo University, Ago-Iwoye, Ogun State, Nigeria \\ Correspondence: Raimi A. Asiyanbola, Department of Geography and Regional Planning, Olabisi Onabanjo \\ University, Ago-Iwoye, Ogun State, Nigeria. E-mail: siyraimi@yahoo.com, demisyra@hotmail.com or \\ asiyanbolaabidemi@yahoo.com
}

$\begin{array}{lc}\text { Received: October 27, } 2012 & \text { Accepted: November 12, } 2012 \quad \text { Online Published: December 7, } 2012 \\ \text { doi:10.5539/jgg.v5n1p45 } & \text { URL: http://dx.doi.org/10.5539/jgg.v5n1p45 }\end{array}$

\begin{abstract}
The paper examines gender differences in the experience of housing in Ibadan, Nigeria. The data used is from a larger household survey carried out by the author in Ibadan, Nigeria. Analysis of variance, paired samples ' $t$ ' test, and multiple linear regression statistical techniques are used to analyze the data. Significant intra-urban variation is found in women's satisfaction with housing in the following order: high density < medium density $<$ low density residential zones. Significant gender differences are found in the aspects of housing that woman and man are especially interested. Men appear to be more interested in the living room than women while women appear to be more interested in the bedroom and kitchen than men. Women felt more that their daily activities are adversely affected by housing attributes than men. House location distance to the various activities is found to have the greatest effects on both women and men's daily activities, followed by housing unit condition and neighbourhood facilities/services condition. Effect of house location distance is found to be greater for men while the effects of neighbourhood facilities/services and housing unit conditions are found to be greater for women. Gender sensitive policy implications are discussed in the paper.
\end{abstract}

Keywords: gender, housing, Ibadan, Nigeria

\section{Introduction}

One of the most basic human needs which have a profound impact on general well-being is housing. As a prerequisite for survival, housing only ranks second to food (Onibokun, 1985; Adeniyi, 1985). According to the definition given by the World Health Organization (WHO), housing is a residential environment that includes the physical structure that man uses for shelter, all necessary services, facilities, equipment, and devices needed or desired for the physical and mental health and social well-being of the family and individual. Housing encompasses far more than living space and shelter (Knox, 1995). Its nature and value are determined by its varied services, which include neighbourhood amenities, access to education, health facilities and security, in addition to shelter.

The importance and significance of housing, coupled with its multifaceted nature, explains why different disciplines study housing. Such disciplines include: Geography, Urban and Regional Planning, Economics, Sociology etc. Like other aspects of human geography, urban geographers are concerned with the spatial and behavioural aspects of housing, the neighbourhoods that these units encompass, and the residents themselves (Kxox, 1996). In pursuing these issues, urban geographers have adopted a variety of approaches to knowledge and understanding. Knox (1995), for example, notes that four main approaches have been identifiable in the literature of urban geography. These four approaches are scientific approach, behavioural approach, radical approach and poststructuralist approach. Out of these four main approaches, Johnston (1996:50) notes that scientific approach, of quantification, theorizing and spatial science, has dominated researches. Remarkably, the scientific approach to gathering knowledge incorporates a stance of anonymity, neutrality, objectivity and universality (Seager, 1992). By shaping housing research in the mode of scientific neutrality, the assumption of collectivity takes precedence over the possibility of gender differences in housing concerns and experiences. In addition, the stance of "neutral" in the studies of consumption patterns and production of housing tends to mask the potential conflict between the interests of men and women, and of particular groups of both men and women 
(Seager 1992; Young 1995; Moser 1993, etc.). Furthermore, the literature is silent on the effects of gender and its social construction on women's housing experience.

\section{A Brief Literature Review}

In devising new housing planning and policies, there are age-long assumptions particularly about households which do not fit the reality of women's lives (Agbola, 1990b; Moser, 1992; 1993; Woods, 1994; Young, 1995; Pascall, 1997; etc.). Hitherto, most researches are based on the conception of the household defined as a spatial unit where members live in the same dwelling and share basic domestic and/or reproduction activities such as cooking and eating (Chant, 1997; Young, 1995; Mishra, 1992; Robertson, 1984; Harris, 1994; etc.). Households are seen as natural units. This conception of households is based on the following assumptions: that households are constituted around relationships centered on marriage and parenthood, that co-residence is a defining feature, that the housing unit and the consumption unit are co-existence and that members of the unit pool and share economic resources, and that within the household there is a clear division of labour based on gender - the man of the family, as the breadwinner is primarily involved in productive work outside the home, while the woman as the house-wife and "housemaker" takes overall responsibility for the reproductive and domestic work involved in the organization of the household. These conceptions of the households have been criticized in the literature. Households mean different things to different people in different places, and there is growing debate on the desirability or otherwise of generating definitions which might be universally applicable (Chant, 1997). Households are not homogenous in terms of family structure. Women in the households perform "triple role" (Moser, 1992; 1993; Brent, 1991; Young, 1995). First, women's work includes reproductive work; childbearing and rearing responsibilities. Second it includes productive work and thirdly, women's work increasingly includes community managing work. Women are severely constrained by the burden of simultaneously balancing these three roles.

Thus in the housing market, women have long been made invisible. If women are discussed, authors often assume stereotyped and fixed roles. In some other studies, brief recognition may be given to gender differences, but their significance is dismissed in mere generalizations (Monk \& Hanson, 1982; Seager, 1992; UNCHS, 1996). In fact, until recently women remained invisible in many analyses of social space and from discussions of development theory and practice (Braidotti et al., 1994; Short, 1996; etc.). Yet women are the major consumers and users of shelter and infrastructure (Agbola, 1990a). According to UN statistics, women perform two-thirds of the world's work, earn one-tenth of the world's income and are two-thirds of the world's illiterates. Women constitute half of the world's population but own only one per cent of its property (Williams, 1994; UNCHS, 1996).

One of the most significant developments in housing during the 1980s and early 1990s was the increasing understanding of the discrimination faced by women in most, if not all, aspects of housing and basic services (UNCHS, 1996). Recent feminist literature asserts that men's conception, experience and use of space is different (McDowell, 1983; Seager, 1992; Weisman, 1992; etc.). It is asserted in the literature that worldwide, women assess urban environments differently from men, in terms of perceived opportunity, safety and access (Wekerle et al., 1980; Ardener, 1981; McDowell, 1983; Holcomb, 1984). Other feminist arguments in the literature have focused on the "environmental fit" among the activities that characterize women's daily lives and the design of dwellings, neighbourhoods, and cities (Weisman, 1992; Seager, 1992; Moser, 1993; Peterson et al., 1978; Short, 1996; etc.). In the literature, it is asserted that there are locational, environmental and architectural forms - high-rise flats, peripheral estates, and under serviced suburbs - which are especially hostile to women's needs and which often extract unnecessary costs from them (Cater \& Trevor, 1989; UNCHS, 1996; Pascall, 1997). The existing spatial arrangement is seen as tending to work for men but against women. This is argued as no accident, but as logical outcome of male power and female powerlessness. Cater and Trevor (1969) for example, noted that all the crucial decisions about the built structures of cities and regions were and are still being taken by males and they have constructed man-oriented geographic space. Even where women have been included in the calculations, this has been women as seen through men's eyes, women's needs as defined by men and not by women themselves (Cater \& Trevor, 1989).

Thus women's urban experience is argued to be inadequately represented by conventional urban theories and models that describe the development and consequences of different urban forms. Feminist have argued that the differences between men and women run through all aspects of urban life: in commuting patterns and transportation use, in patterns of housing and homelessness, in labour force participation and work opportunities and in the use of urban social space (Seager, 1992; Weisman, 1992). In fact, Harold (1995) argued that, gender as represented by 'he' or 'she' will produce different reactions to city space. Also, according to him, that the female view of the city space should be different depend on two factors - the roles/responsibilities and the 
physical strength. He noted that the old stereotype of man as the breadwinner and woman as the homemaker has become outmoded. He remarked that hitherto, the real problem is that no great corpus of work exists on which to draw.

In the literature women are argued to be generally far more severely affected by poor and over-crowded housing conditions, inadequate provision of water, sanitation, health-care, schools and nurseries than men because they take more responsibility for looking after infants and children, caring for sick family members and managing the household (Beall \& Levy, 1994; UNCHS, 1996). Thus, UNCHS (1996) stresses the need to assess women's demands for shelter, goods and services and to encourage the design and implementation of innovative programmes that will increase women's participation in shelter management. Also Agbola (1990a:184) asserts that planning and execution of housing development, either at the individual and or at national level, cannot or may not succeed unless the needs and contributions of women, who will be affected by them are clearly understood and addressed at every stage of housing planning and implementation.

Even though existing housing studies in Nigeria indicate a rather diffused research interest, the approach has always been gender neutral, with an implicit assumption of male heads of households. For example, Onibokun's (1983) review of the existing literature on housing quality and urban form in Nigeria indicates that the central theme of researches has been identification, description and analysis of the quality and character of housing in Nigeria. In addition, most of the housing publications are researches on different communities in Nigeria, focusing on such areas as: poor housing quality; slum clearance and slum upgrading schemes; housing preference, demand, finance and environmental perception vis-à-vis residential desirability and values; evolution process of residential morphology in some selected urban centers (Onibokun, 1983).

Apart from these scholars' works on housing, the government has at different times embarked on various housing programmes and policies which are often the targets of critical evaluation and study. The housing schemes have been faced with several bottlenecks that prevented the full realization of the ultimate objectives for which such schemes were originally designed (Onibokun, 1985; Agbola, 1985; 1986; 1990c; 1998). Of significance to the present discourse, however, is the fact that public housing policy is evaluated relative to its impact on the poor and not necessarily on women.

In short, empirical evidence on women's actual experience of housing is rare in Nigeria. As Agbola (1990a) and Asiyanbola (1997) notes, there has been little contribution of researches on women's housing situation. An exception to the research orientation common in Nigeria is Agbola's work (1990b) and Olatubara's work (2003) in which they examined the role of women in housing development and women's participation in residential location decision-making respectively in Ibadan, Oyo State, Nigeria. The present study adds to the literature by examining gender differences in the experience of housing. The null hypotheses tested in the paper are that (i) there is no intra-urban variation in women's satisfaction with housing units, (ii) there is no significant gender differences in the aspects of housing units that women and men take special interest in, and (iii) there is no significant variation in the impact of housing on women and men's daily activities. Here we expect that (a) there is no gender difference in the felt adverse effect of aspects of housing on daily activities; and (b) there is no significant relationship between housing attributes and gender attributes - no significant gender difference exists in the effects of the housing attributes on the daily activities of women and men.

\section{Method of Data Collection and Analysis}

Data base used in the paper were obtained from a cross-sectional survey of households in Ibadan, Oyo State, Nigeria between 1999 and 2001. Due to cost consideration, a total of seven hundred and twenty-one households were selected as the sample size. To make for effective and objective coverage, due to non availability of the list of all households in each locality in Ibadan, the number of questionnaire forms administered in each locality was proportional to the total number of estimated households in each locality. For the purpose of intra-urban analysis, each of the locality in Ibadan municipal area as defined by the National Population Commission (NPC) was accordingly sorted into four residential areas - high density residential area (comprising traditional core high density residential area of Ibadan and non-traditional core high density residential area), medium density residential area and low density residential area - according to where it was located. This was done following existing studies and in addition to reconnaissance survey and consultation with town planners.

The sampling procedure adopted was aimed at sampling along the major streets in each locality. Systematic random sampling was used in the selection of houses along the streets. Information was collected on women's satisfaction with the housing units delivered in Ibadan, some aspects of housing unit that women and men take special interest in, felt adverse effect of some aspects of housing on women and men's daily activities, gender 
attributes and the housing attributes. Analysis of variance (ANOVA), paired samples ' $t$ ' test, and multiple linear regression statistical techniques are used to test the hypotheses.

\section{Results and Discusion}

\subsection{Women's Satisfaction with Different Aspects of Housing in Ibadan}

Table 1 shows the mean and the standard deviation of women's satisfaction with housing in Ibadan.

Table 1. Mean and standard deviation of women's satisfaction with housing in Ibadan

\begin{tabular}{lll}
\hline Residential Areas & Mean & Std. Dev. \\
\hline Traditional core high density & 2.55 & .707 \\
Non-traditional core high density & 2.72 & .692 \\
Medium density residential area & 2.81 & .751 \\
Low density residential area & 3.10 & .690 \\
\hline
\end{tabular}

The table is derived from Appendix 1 which shows the mean, standard deviation and the analysis of variance (ANOVA) of women's satisfaction with different aspects of housing in Ibadan. The aspects of housing considered include the following: kitchen, balcony/corridor/verandah, backyard, bathroom, toilet, ventilation, water supply, noise, pollution, safety, power supply and courtyard. These variables are measured on a four point likeart scale ( strongly dissatisfied $=1$; dissatisfied $=2$; satisfied $=3$; strongly satisfied $=4$ ).

Table 1 shows that the average score of the women satisfaction with housing is highest in the low density residential area (3.10), followed by the average score in the medium density residential area (2.81), non-traditional high density residential area (2.72) and the traditional core high density residential area of Ibadan (2.55). This result implies that women are more satisfied with housing in the low density residential area and least satisfied with housing in the core area of Ibadan. The reason may be due to the fact that overcrowding of houses and people as well as poor condition of housing are more in the traditional core area of Ibadan compared to all other areas. Also, the conditions of housing and associated basic infrastructures are better in the low density residential areas compared to other areas of Ibadan. The result of the analysis of variance (ANOVA) shows that the $F$ value is 16.485 , the significant value is .000 (Table 2). This result is significant at $p<.01$. This result implies that intra-urban variation observed in the satisfaction of women with housing in Ibadan is significant.

Table 2. ANOVA test of intra-urban variation in women's satisfaction with housing in Ibadan

\begin{tabular}{lccccc}
\hline & Sum of Squares & df & Mean Square & F & Sig. \\
\hline Between Groups & 661.655 & 3 & 220.550 & 15.652 & .000 \\
Within Groups & 10103.466 & 717 & & & \\
Total & 10765.121 & 720 & & & \\
\hline
\end{tabular}

$* *$ Significant at $\mathrm{p}<.01$.

The mean values in Table 1 are used to draw the map showing the intra-urban variations in the level of housing satisfaction of women in Ibadan. This is shown in Figure 1. Areas of very low satisfaction are found in the traditional core areas of Ibadan and it includes such neighbourhoods as Beere, Oje, Gege, Foko, Agbeni, Isale-Osi, Oja'ba etc. Areas of low satisfaction cover neighbourhoods in the non-traditional core high density residential areas and they include Agbowo, Orogun, Molete, Odo-Ona, Apata, etc. Areas of medium and high satisfaction are found in the sections of the city collectively described as medium and high income residential zones. Neighbourhoods in these areas include Idi-Ape, Ring-Road, Challenge, Felele, Orita-Bashorun, Ikolaba, Agodi, Bodija, Iyaganku, etc. 


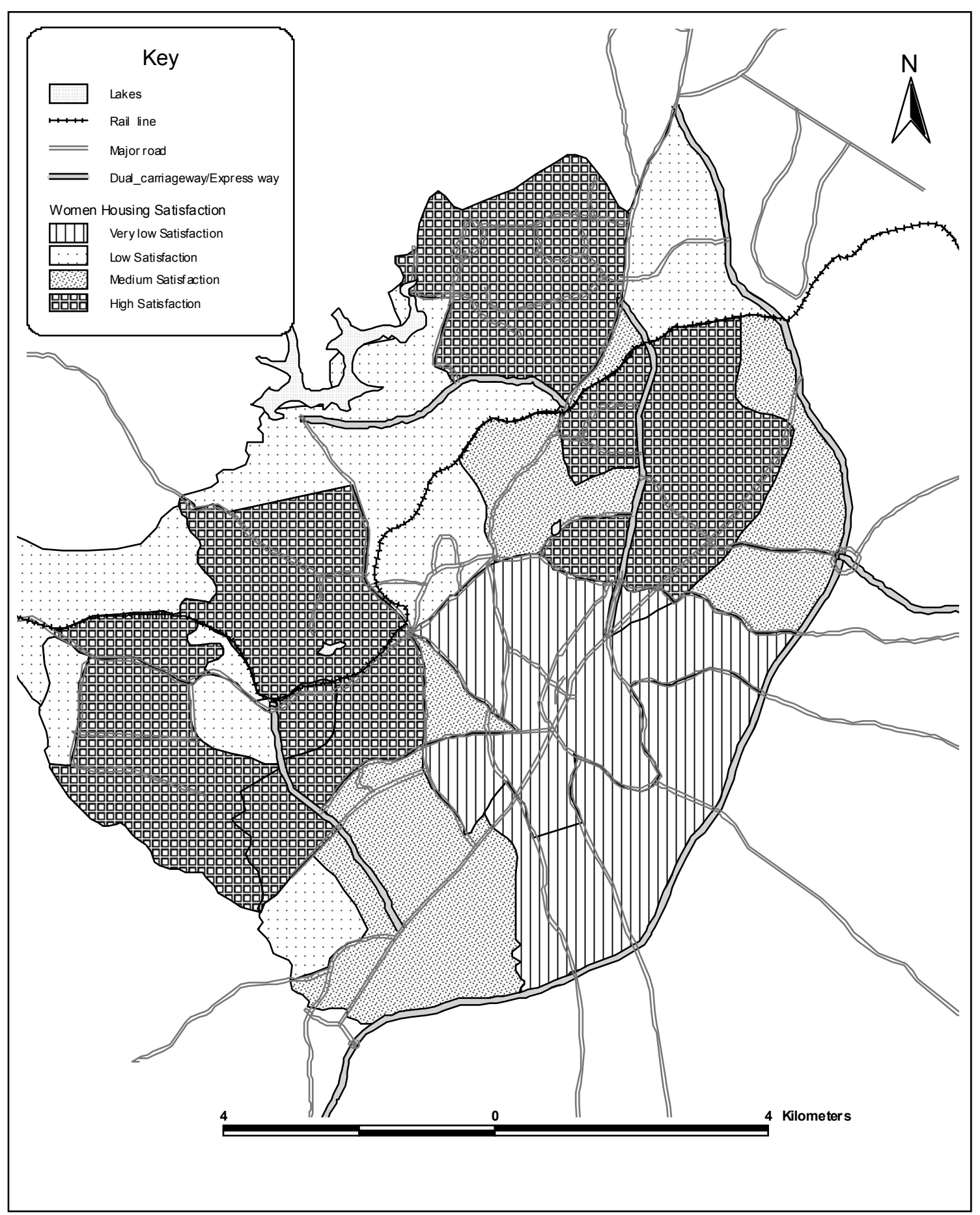

Figure 1. Spatial variations in women's housing satisfaction in Ibadan

\subsection{Gender and Housing Structural Units}

Housing unit occupied by households in most cases comprise basically of a living room, bedroom(s), a kitchen, a bathroom, a toilet and the parking space/garage. Due to gender differences in the socio-cultural roles/responsibilities in the household, we expect gender differences in the aspects of housing structural units in which women and men would be interested in Ibadan. Table 3 show the percentage of women and men that are specially interested in each of these aspects of housing structural units in each of the residential areas in Ibadan. 
Table 3. Percentage figure of women and men that take special interest in different aspects of the household housing structural unit

\begin{tabular}{|c|c|c|c|c|c|c|c|c|c|c|}
\hline \multirow{2}{*}{$\begin{array}{l}\text { Aspects of the } \\
\text { household } \\
\text { housing } \\
\text { structural unit }\end{array}$} & \multicolumn{2}{|c|}{$\begin{array}{l}\text { Traditional core } \\
\text { high density } \\
\text { residential area } \\
\end{array}$} & \multicolumn{2}{|c|}{$\begin{array}{l}\text { Non-traditional } \\
\text { core high density } \\
\text { residential area }\end{array}$} & \multicolumn{2}{|c|}{$\begin{array}{l}\text { Medium density } \\
\text { residential area }\end{array}$} & \multicolumn{2}{|c|}{$\begin{array}{l}\text { Low density } \\
\text { residential area }\end{array}$} & \multicolumn{2}{|c|}{$\begin{array}{l}\text { All the } \\
\text { residential areas }\end{array}$} \\
\hline & $\begin{array}{l}\text { Women } \\
(\mathrm{n}=384) \\
(\%)\end{array}$ & $\begin{array}{l}\text { Men } \\
(\mathrm{n}=292) \\
(\%)\end{array}$ & $\begin{array}{l}\text { Women } \\
(\mathrm{n}=150) \\
(\%)\end{array}$ & $\begin{array}{l}\text { Men } \\
(\mathrm{n}=114) \\
(\%)\end{array}$ & $\begin{array}{l}\text { Women } \\
(\mathrm{n}=136) \\
(\%)\end{array}$ & $\begin{array}{l}\text { Men } \\
(\mathrm{n}=125) \\
(\%)\end{array}$ & $\begin{array}{l}\text { Women } \\
(\mathrm{n}=51) \\
(\%)\end{array}$ & $\begin{array}{l}\text { Men } \\
(\mathrm{n}=40) \\
(\%)\end{array}$ & $\begin{array}{l}\text { Women } \\
(\mathrm{n}=721) \\
(\%)\end{array}$ & $\begin{array}{l}\text { Men } \\
(\mathrm{n}=571) \\
(\%)\end{array}$ \\
\hline Living room & 42.0 & 65.8 & 32.7 & 70.5 & 41.2 & 65.3 & 66.7 & 65.0 & 45.5 & 66.6 \\
\hline Bedroom & 55.2 & 37.6 & 53.4 & 40.0 & 38.9 & 41.1 & 60.8 & 55.0 & 52.1 & 40.1 \\
\hline Kitchen & 32.6 & 14.4 & 49.3 & 18.3 & 44.1 & 16.9 & 43.1 & 35.0 & 39.0 & 17.2 \\
\hline Bathroom & 15.4 & 13.7 & 17.4 & 13.9 & 16.9 & 12.9 & 25.5 & 22.5 & 16.7 & 14.2 \\
\hline Toilet & 22.6 & 21.2 & 36.7 & 30.5 & 36.8 & 33.9 & 19.6 & 22.5 & 28.1 & 25.9 \\
\hline Parking-/garage & 5.0 & 8.2 & 6.7 & 9.6 & 14.0 & 16.1 & 21.6 & 20.0 & 8.2 & 11.1 \\
\hline
\end{tabular}

Men appear to be more especially interested in the living room than women. In all the residential areas taken together, 46.0 percent of women and 67.0 percent of men are specially interested in the living room. Women appear to be more interested in the bedroom than men. In all the residential areas together, 52.0 percent of women and 40.0 percent of men are specially interested in the bedroom. Women appear to more especially interested in the kitchen and bathroom of their house than men. In each of the residential areas in Ibadan, higher percentages of women are specially interested in the kitchen and bathroom of their house.

In all the residential areas together, 28.0 percent of women and 26.0 percent of men take special interest in the toilet. This also shows that compared to men, women appear to be more interested in the toilet in their house. In the case of the parking/garage, men appear to be more interested. In all the residential areas together, 8.0 percent of women and 11.0 percent of men take special interest in the parking/garage.

Table 4 shows the result of the paired " $\mathrm{t}$ " test statistics of each aspects of housing structural unit considered. The result of the paired " $\mathrm{t}$ " test shows significant differences at $\mathrm{p}<.01$ in the interest of women and men in such structural aspects of housing as living room, bedroom and the kitchen.

Table 4. Paired samples " $t$ " Test of some aspects of housing that Women and Men take special interest in Ibadan

\begin{tabular}{llll}
\hline Some aspects of housing & "t”-value & d.f. & Sig. \\
\hline Living Room & $-9.087^{* *}$ & 570 & .000 \\
Bedroom & $3.190^{* *}$ & 570 & .001 \\
Kitchen & $10.501^{* *}$ & 570 & .000 \\
Bathroom & 1.192 & 570 & .234 \\
Toilet & 1.205 & 570 & .229 \\
Parking space/garage & -.762 & 570 & .446 \\
\hline
\end{tabular}

$* *$ Significant at $\mathrm{p}<.01$.

4.4 Gender Differences in the Felt Adverse Effect of Some Aspects of Housing on Women's and Men's Daily Activities in Ibadan

Because women are the prime users of housing and settlement-level infrastructure, they are asserted to be more affected than any other group particularly men by the condition and the way the dwelling is planned. This assertion is examined here. Aspects of the dwelling units considered are: house location, kitchen space, power supply, water supply, neighbourhood road, space for income generating activities and the living space. These 
variables are carefully selected to cut across the three attributes of housing which are locational, neighbourhood and structural attributes. Respondents were asked to tick any of those aspects of housing that adversely affect their daily activities. Table 5 show the percentage figures of women and men whose daily activities are adversely affected by each of those aspects of housing. From the table, it appears that women are more adversely affected than men by the house location, kitchen space, power supply, water supply, neighbourhood road, space for income generating activities and the living space.

Table 5. Percentage figures of women and men that their daily activities are adversely affected by the different aspects of housing

\begin{tabular}{|c|c|c|c|c|c|c|c|c|c|c|}
\hline \multirow{2}{*}{$\begin{array}{l}\text { Aspects of the } \\
\text { household } \\
\text { housing }\end{array}$} & \multicolumn{2}{|c|}{$\begin{array}{l}\text { Traditional core } \\
\text { high density } \\
\text { residential area }\end{array}$} & \multicolumn{2}{|c|}{$\begin{array}{l}\text { Non-traditional } \\
\text { core high density } \\
\text { residential area }\end{array}$} & \multicolumn{2}{|c|}{$\begin{array}{l}\text { Medium density } \\
\text { residential area }\end{array}$} & \multicolumn{2}{|c|}{$\begin{array}{l}\text { Low density } \\
\text { residential area }\end{array}$} & \multicolumn{2}{|c|}{$\begin{array}{l}\text { All the residential } \\
\text { areas }\end{array}$} \\
\hline & $\begin{array}{l}\text { Women } \\
(\mathrm{n}=384) \\
(\%)\end{array}$ & $\begin{array}{l}\text { Men } \\
(\mathrm{n}=292) \\
(\%)\end{array}$ & $\begin{array}{l}\text { Women } \\
(\mathrm{n}=150) \\
(\%)\end{array}$ & $\begin{array}{l}\text { Men } \\
(n=114) \\
(\%)\end{array}$ & $\begin{array}{l}\text { Women } \\
(\mathrm{n}=136) \\
(\%)\end{array}$ & $\begin{array}{l}\text { Men } \\
(\mathrm{n}=125) \\
(\%)\end{array}$ & $\begin{array}{l}\text { Women } \\
(\mathrm{n}=51) \\
(\%)\end{array}$ & $\begin{array}{l}\text { Men } \\
(\mathrm{n}=40) \\
(\%)\end{array}$ & $\begin{array}{l}\text { Women } \\
(\mathrm{n}=721) \\
(\%)\end{array}$ & $\begin{array}{l}\text { Men } \\
(\mathrm{n}=571) \\
(\%)\end{array}$ \\
\hline $\begin{array}{l}\text { Location of the } \\
\text { house }\end{array}$ & 25.1 & 21.6 & 18.7 & 22.8 & 22.1 & 14.4 & 13.7 & 10.0 & 22.4 & 19.4 \\
\hline Kitchen & 18.0 & 10.3 & 17.4 & 11.4 & 11.8 & 8.8 & 11.8 & 5.0 & 16.2 & 9.8 \\
\hline Power supply & 62.5 & 61.3 & 66.0 & 49.1 & 64.0 & 66.4 & 43.1 & 47.5 & 62.1 & 59.0 \\
\hline Water supply & 35.2 & 26.4 & 35.0 & 23.7 & 41.9 & 35.4 & 20.6 & 11.3 & 35.4 & 26.8 \\
\hline $\begin{array}{l}\text { Neighbou-rhood } \\
\text { road condition }\end{array}$ & 24.0 & 18.2 & 36.0 & 28.9 & 35.3 & 34.4 & 7.8 & 12.5 & 27.5 & 23.5 \\
\hline $\begin{array}{l}\text { Space for } \\
\text { income } \\
\text { generation }\end{array}$ & 17.7 & 7.5 & 18.0 & 9.6 & 8.8 & 8.0 & 9.8 & 7.5 & 15.5 & 8.1 \\
\hline Living space & 19.3 & 13.0 & 10.7 & 10.5 & 5.9 & 4.0 & 2.0 & 2.5 & 13.7 & 9.8 \\
\hline
\end{tabular}

Table 6 shows the result of the paired samples " $\mathrm{t}$ " test statistics of women and men that felt that their daily activities are adversely affected by each aspect of housing considered in Ibadan. The result of the overall paired " $\mathrm{t}$ " tests shows that there are significant gender differences at $p<.01$ in the felt adverse effects of housing with women feeling more adversely affected by housing than men.

Table 6. Result of the paired samples' $t$ ' Test of the felt adverse effects of some aspects of housing on women and men in Ibadan

\begin{tabular}{llll}
\hline Variables & 't' value & d.f. & Sig. \\
\hline Location of the house & $2.477^{*}$ & 570 & .014 \\
Kitchen & $3.292^{* *}$ & 570 & .001 \\
Power supply & $2.154^{*}$ & 570 & .032 \\
Water supply & $4.988^{* *}$ & 570 & .000 \\
Neighbourhood road condition & $2.471^{*}$ & 570 & .014 \\
Space for income generation & $4.218^{* *}$ & 570 & .000 \\
Living space & $1.985^{*}$ & 570 & .048 \\
Overall & $6.182^{* *}$ & 570 & .000 \\
\hline
\end{tabular}

** Significant at $\mathrm{p}<.01$.

* Significant at $\mathrm{p}<.05$. 


\section{Gender Attributes and the Housing Attributes}

The purpose here is to examine gender differences in the impacts of housing attributes on the daily activities of women and men using multiple linear regression statistical techniques. Due to the difficulties in measuring the qualities of femaleness and maleness, the sexual division of labour as reflected by the daily activities of women and men is used as a manifestation of women and men gender attributes. As Bernard argues:

"The division of labour by sex means that the work group becomes also a sex group. The very nature of maleness and femaleness becomes embedded in the sexual division of labour. One's sex and one's work are part of one another. One's work defines one's gender" (Bernard, 1981).

Housing attributes comprise the locational attributes, neighbourhood attributes and the structural attributes (Arimah, 1990). The location of the house determines the distance to various services including the distance to the work place. The neighbourhood attributes refer to the facilities/utilities and services available in the neighbourhood. The conditions of the facilities/utilities and services available in the neighbourhood in which the house is located are important as these determine the condition of the housing infrastructural services. The structural attributes of the housing unit refer to the condition of the building unit including the design of the building. This is important as it determines the state of the housing maintenance, availability of space for various activities in the house including income generating activities. The hypothesis tested here is that there is no significant relationship between the housing attributes and the gender attributes. We expect that there is no gender difference in the impact of the housing attributes on the daily activities of women and men. Multiple linear regression technique is used to test the hypothesis. Table 7 shows the definition of the dependent $(\mathrm{Y})$ and the independent $(\mathrm{Xi})$ variables used in the analysis.

Table 7. Definition of the dependent $(\mathrm{Y})$ and independent variables used in the analysis of impact of housing attributes on women's and men's daily activities

\begin{tabular}{|c|c|c|}
\hline Code & Variable & How measured \\
\hline Y & Daily Activities & $\begin{array}{l}\text { - } 1 \text { each if experiencing difficulties in doing the following daily activities: going } \\
\text { to workplace, taking the children to childcare/school, getting rid of household } \\
\text { waste, fetching water, cooking, cleaning the house and the surrounding, childcare, } \\
\text { and, domestic activities generally }\end{array}$ \\
\hline $\mathrm{X}_{1}$ & $\begin{array}{l}\text { Housing Unit } \\
\text { condition }\end{array}$ & $\begin{array}{l}-1 \text { if there are any cracks on the wall of the house } \\
-1 \text { if there are any cracks on the floors of the house } \\
-1 \text { if the house roof is leaking and needs repairs } \\
-1 \text { if the house needs general repair } \\
-1 \text { if pests are prevalent in the house } \\
-1 \text { each if dissatisfied with each of the following } \\
\text { aspects of housing: kitchen, balcony/ } \\
\text { corridor/verandah, backyard, bathroom, toilet, } \\
\text { ventilation and courtyard }\end{array}$ \\
\hline $\mathrm{X}_{2}$ & $\begin{array}{l}\text { Neighbourhood } \\
\text { facilities/services }\end{array}$ & $\begin{array}{l}\text { - } 1 \text { each if the following neighbourhood facilities/services are bad: } \\
\text { neighbourhood road, garbage collection, public transport, street light, } \\
\text { neighbourhood water supply, power supply, school quality, shops, and the general } \\
\text { condition of the neighbourhood }\end{array}$ \\
\hline$X_{3}$ & $\begin{array}{l}\text { House location } \\
\text { distance }\end{array}$ & $\begin{array}{l}\text { - } 1 \text { each if the house distance to each of the following activity areas is far: } \\
\text { workplace, shopping centre, children school and childcare centre, where they } \\
\text { fetch water and dispose solid waste }\end{array}$ \\
\hline
\end{tabular}

The effects of the housing attributes as indicated by the proportion of variance explained by each of housing attribute variables on women's and men's daily activities is shown in Table 9 (women) and Table 10 (men). 
Table 9. Effects of housing attributes on women's daily activities

\begin{tabular}{|c|c|c|c|c|c|c|c|c|}
\hline \multirow[t]{2}{*}{ Model } & \multirow[t]{2}{*}{ Variable } & \multirow{2}{*}{$\begin{array}{l}\text { Level of } \\
\text { Explanation } \\
\text { (R-Square } \\
\text { Change) }\end{array}$} & \multirow[t]{2}{*}{ R-Square } & \multirow[t]{2}{*}{ Std. Error } & \multirow[t]{2}{*}{ F-Change } & \multirow[t]{2}{*}{$\begin{array}{l}\text { Sig. F } \\
\text { Change }\end{array}$} & \multicolumn{2}{|c|}{$\begin{array}{l}\text { Multiple Stepwise } \\
\text { Regression } \\
\text { ANOVA Result }\end{array}$} \\
\hline & & & & & & & F-value & Sig. \\
\hline 1 & $\begin{array}{l}\text { House location } \\
\text { distance }\end{array}$ & .078 & .078 & 2.0436 & $8.675^{* *}$ & .000 & $8.675^{* *}$ & .000 \\
\hline 2 & $\begin{array}{l}\text { Neighbourhood } \\
\text { facilities \& } \\
\text { services } \\
\text { condition }\end{array}$ & .032 & .110 & 2.0208 & $2.796^{* *}$ & .003 & $5.454 * *$ & .000 \\
\hline 3 & $\begin{array}{l}\text { Housing Unit } \\
\text { condition }\end{array}$ & .043 & .153 & 1.9870 & $3.195 * *$ & .000 & $4.645^{* *}$ & .000 \\
\hline
\end{tabular}

** Significant at $\mathrm{p}<.01$.

* Significant at $\mathrm{p}<.05$.

Table 10. Effects of housing attributes on men's daily activities

\begin{tabular}{|c|c|c|c|c|c|c|c|c|}
\hline \multirow[t]{2}{*}{ Model } & \multirow[t]{2}{*}{ Variable } & \multirow{2}{*}{$\begin{array}{l}\text { Level of } \\
\text { Explanation } \\
\text { (R-Square } \\
\text { Change) } \\
(\%)\end{array}$} & \multirow[t]{2}{*}{ R-Square } & \multirow[t]{2}{*}{ Std. Error } & \multirow[t]{2}{*}{ F-Change } & \multirow[t]{2}{*}{$\begin{array}{l}\text { Sig. F } \\
\text { Change }\end{array}$} & \multicolumn{2}{|c|}{$\begin{array}{l}\text { Multiple Stepwise } \\
\text { Regression } \\
\text { ANOVA Result }\end{array}$} \\
\hline & & & & & & & F-value & Sig. \\
\hline 1 & $\begin{array}{l}\text { House location } \\
\text { distance }\end{array}$ & .279 & .279 & 1.8533 & $219.959 * *$ & .000 & $219.959 * *$ & .000 \\
\hline 2 & $\begin{array}{l}\text { Neighbourhood } \\
\text { facilities \& } \\
\text { services } \\
\text { condition }\end{array}$ & .001 & .280 & 1.8539 & .610 & .435 & $110.209 * *$ & .000 \\
\hline 3 & $\begin{array}{l}\text { Housing Unit } \\
\text { condition }\end{array}$ & .003 & .283 & 1.8514 & 2.564 & .110 & $74.530^{* *}$ & .000 \\
\hline
\end{tabular}

The analysis of variance (ANOVA) of the multiple stepwise linear regression models shows that the F- value of each of the stepwise multiple linear regression models is significant at $\mathrm{p}<.01$ (Tables 9 and 10). This implies that the overall regression model is significant. In essence, this means that all the independent or explanatory variables taken together can be used to explain the difficulties women and men experience in carrying out their daily activities. In essence, this implies that there is a relationship between gender attributes and housing attributes. The low value of R-Square may be an indication that there are other variables apart from housing attributes that have effect on the level of difficulties experienced in carrying out daily activities. This could be explored in further studies. Nevertheless, in the present study, the main interest is the relative impacts of each of the housing attributes variables on women and men's daily activities. This is clearly seen in Tables 9 (women) and 10 (men).

From Table 9 the most significant variables for women are: house location distance, housing unit condition and neighbourhood facilities/services condition, while for men, the most significant variable is the house location distance to the various activity areas (Table 10). This result could be due to gender roles/responsibilities in the households. Men as the major breadwinners in the household are greatly affected by the distance of the house particularly to the workplace. Women, also due to their triple roles in the household - household responsibilities, 
reproductive role and involvement in productive activities - are affected by the housing unit condition, neighbourhood facilities/services condition and the house location distances to the various activity areas.

The order of relative importance of the independent variables shows that house location distance to the various activities has the greatest impacts on both women (.078) and men (.279). This is followed by housing unit condition (.043 for women and .003 for men) and neighbourhood facilities/services condition (.032 for women and .001 for men) (see Table 9 and 10).

A closer examination of the proportion of variance (R-Square Change) of each of the housing attributes variables shows that only the R-Square Change value of the house location variable of men (.279) is higher than that of the women (.078) while in each of the other housing attributes the R-Square Change value of women is higher than that of the men. This result suggests that the effect of the house location distance is more on the men than women, while the effects of the neighbourhood facilities/services and housing unit condition are more on women than men.

These results may be due to the fact that women are the primary consumers and users of house and facilities/services and so they are more affected by any neighbourhood facilities/services and structural inadequacy than men. This is so because they are more responsible for housework and child caring activities than men. Besides they spend more time at home than men.

\section{Summary, Implications of the Findings and Conclusion}

This paper has examined gender differences in the experience of housing in Ibadan, Nigeria. The findings show that there is a significant intra-urban variation at $\mathrm{p}<.01$ in the satisfaction of women with houses delivered. Significant gender differences at $\mathrm{p}<.01$ is also found in the following aspects of housing structural units in which women and men are specially interested: living room, bedroom, and kitchen. Men appear to be more interested in the living room than women while women appear to be more interested in the bedroom and kitchen than men. Also significant gender differences at $\mathrm{p}<.01$ are found in the overall felt adverse effects of aspects of housing on women and men's daily activities. Women felt more that their daily activities are adversely affected than men. Significant gender relationship is found between gender attributes and housing attributes at $p<.01$. The order of relative importance of the independent variables shows that house location distance to the various activities has the greatest impacts on both women and men. This is followed by housing unit condition and neighbourhood facilities/services condition. Gender differences are observed in the magnitude of the effects of housing attributes on women and men. The effect of the house location distance is found to be greater for men while the effects of the neighbourhood facilities/services and housing unit condition are found to be greater for women.

Previous empirical and theoretical discussions in literature assumed the universality of women's and men's experience. For instance, Robinson (1998) note that the human geography techniques and models, many of which originated within geography from the pioneering studies in the 1960s, were applied in research that completely ignored gender. According to him, although there were references to consumers, decision-makers and heads of households, there was no attempt to distinguish between the different realities confronting men and women, and the differential power relations associated with gender (Jackson, 1990). Gender was largely a taken-for-granted variable and the different nature of women's lives was simply ignored.

This study, in line with various other recent studies has sought to uncover women's experiences in contrast to men's experience. This approach has thrown into sharp focus the different types of experience by men and women. Therefore, it is important to integrate gender consideration into theory and methodology. This is because, by focusing solely upon the male view, not only were women's views being marginalized but vital aspects of people-place interaction were simply ignored (Robinson, 1998).

Hitherto, while it is taken for granted that women should be responsible for tasks such as collecting drinking water and fuel, cooking and washing, keeping homes and land tidy, getting rid of waste, keeping up allotments, bringing up children and caring for the sick and invalids in the home usually fall on their shoulders, it is also assumed that women do not need to be involved in planning interventions in these areas. The focus of professionals engaged in the business of creating dwellings and dwelling environments has been on households defined and interpreted more often as household heads who are men in most cases, whereas women are the primary and major consumers and users of these environments. It is common for the architect, in preparing a programme of requirements for the design of owner-occupied residences, to involve in the process, only the household head (usually a man) who has commissioned him to design a house. Little or no importance is attached to the specific requirements, values, roles and attitudes of women with respect to both the dwelling and its environment (Amole, 1998). This perspective to the creation of dwellings and dwelling environments must change. There is need for approaches to planning and design that are more gender-conscious and sensitive. Such 
approaches to planning as observed in the literature include participatory approach and open-ended 'supports' approach (Amole, 1998; Woolley, 1994). Participatory approach considers the participation of the user in the design process as a fundamental principle of design if the environment is to reflect the needs and aspirations of its users. It is an approach in which women would actively participate in the design and planning of their residential environment. Planners and Architects would have the opportunity to be enlightened by women about the kinds of environments they would want to live in as well as the values they hold about different aspects of the residential environment. Participation should be encouraged at all stages of designing residential environment. The concept of open-ended 'support' is based on the premise that design should be flexible enough to accommodate changes according to the users' specific requirements. The potential of flexibility is of great benefit especially with rapidly changing gender roles and attributes in a developing society as ours. More importantly each woman has the opportunity to modify and complete her home environment to suit her requirement. There is the need for the upgrading of the residential areas. Roads and other basic amenities and facilities need to be provided where they are non-existent.

\section{Acknowledgement}

The author is grateful to Council for the Development of Economic and Social Research in Africa (CODESRIA) for providing small grant for thesis writing for the $\mathrm{PhD}$ research project from which the data for this paper is derived.

\section{References}

Adeniyi, E. O. (1985). Housing in Nigerian National Development. In P. Onibokun (Ed.), Housing in Nigeria: (A book of reading) (pp. 91-104). NISER, Ibadan.

Agbola, T. (1985). Physical Environment Behaviour Patterns and House Forms. (Paper presented at the National Conference on Human Behaviour and the challenge of National Development in Nigeria, held at the Conference Centre, University of Ife (Now Obafemi Awolowo University), Ile Ife, $15^{\text {th }}-19^{\text {th }}$ April).

Agbola, T. (1986). The Nature of Housing Subsidies in Nigeria. Journal of the Nigerian Institute of Town Planners, Vi \& vii (December), 86-98.

Agbola T. (1990a). The Nature of women's Involvement in Housing Development: A survey of the Literature. African Urban Quarterly, 5(3\&4), 178-185.

Agbola. (1990b). The Role of Women in Housing Development. (Centre for Urban and Regional Planning, Faculty of Social Sciences, University of Ibadan, Ibadan).

Agbola, T. (1990c). Affordability and Cost-recovery in Shelter Projects: The Case of Nigeria. Third World Planning Review, 12(1), 105-125.

Agbola, T. (1998). The Housing of Nigerians: A Review of Policy Development and Implimentation. Research Report, No. 14, Development Policy Centre, Ibadan, Nigeria.

Amole, D. (1998). Planned Residential Environments In Nigeria: Implications For Women. In B. Amole (Ed.), Habitat Studies in Nigeria (pp. 79-91). Ibadan: Shaneson C.I. Ltd.

Ardener, S. (1981). Women and Space. London: Croom Helm.

Arimah, B. C. (1990). An analysis of Urban Housing Market in a Developing Country: A Case Study of Ibadan, Nigeria. (Unpublished Ph.D Thesis submitted to the Department of Geography, University of Ibadan, Ibadan).

Asiyanbola, R. A. (1997). Housing Studies and gender Issues: A Review of literature. In A. Bayo (Ed), The House in Nigeria history Place, environment and development. Proceedings of a National symposium $23^{\mathrm{rd}}$ $24^{\text {th }}$ July held at the Conference Centre, Obafemi Awolowo University, Ile Ife. pp. 89-92.

Beall, J., \& Levy, C. (1994). Moving towards the Gendered City. Overview (Paper prepared for the Preparatory Committee for HABITAT II,Geneva, 11-22 April 1994).

Bernard, J. (1981). The Good-Provider Role: Its Rise and Fall. American Psychologist, 36(1), 1-12. http://dx.doi.org/10.1037/0003-066X.36.1.1

Braidotti, R., Ewa, C., Sabine, H., \& Saskia, W. (1994). Women, the Environment and Sustainable Development Toward a Theoretical Synthesis. USA: ZED Books Ltd.

Brent, A. (1991). Why Gender is a Development Issue. In W. Tina, \& M. Candida (Eds.), Changing Perceptions: Working on Gender and Development. Oxford: Oxfam. 
Cater, J., \& Trevor, J. (1989). Social Geography. London: Edward Arnold.

Chant, S. (1997). Women-Headed Households: Diversity and Dynamics in the Developing. London: World, Macmillan.

Harold, C. (1995). The Study of Urban Geography. London: Arnold.

Harris, O. (1984). Households as a Natural Units. In K. Young, C. Wohowitz, \& McCullagh (Eds.), Of Marriage and the Market: Women's Subordination Internationally and its Lessons. London: Routledge.

Holcomb, B. (1984). Women in the City. Urban Geography, 5, 247-254. http://dx.doi.org/10.2747/0272-3638.5.3.247

Jackson, P. (1990). The cultural politics of masculinity: towards a social geography. Transactions of the Institute of British Geographers, 16, 199-213. http://dx.doi.org/10.2307/622614

Johnston, R. J. (1996). Paradigms and Revolution or Evolution. In J. Agnew et al. (Eds.), Human Geography an Essential Anthology (pp. 37-53). U.K.: Blackwell.

Knox, P. (1995). Urban Social Geography: An Introduction. New York: Longman \& John Wiley.

Knox, L. P. (1996). Urban Geography. In K. Adam \& K. Jessica (Eds.), The Social Science Encyclopedia. London: Routledge.

Kramarae, C., \& Spender, D. (1992). Exploding Knowledge. In C. Kramarae \& D. Spender (Eds.), The Knowledge Explosion: Generations of Feminist Scholarship (pp. 1-24). London: Athene Series, Teachers College Press.

McDowell, L. (1983). Towards an understanding of the gender division of urban space. Environmental and Planning D: Society and Space, 1, 59-72.

Mishra, K. (1992). Nishing long house as a Household. In K. Saredamoni (Ed.), Finding the Household: Methodological and Empirical Issues (pp. 135-142) (new Delhi Sage).

Monk, J., \& Hanson, S. (1982). On not excluding Half of the Human Geography. The Professional Geographer, 34(1), 11-23. http://dx.doi.org/10.1111/j.0033-0124.1982.00011.x

Moser, C. O. N. (1992). Housing. In L. Ostrgaard (Ed.), Gender and Development: a Practical Guide (pp. 76-93). London: Routledge.

Moser, C. O. N. (1993). Gender, Planning and Development: Theory, Practice and Training. London: Routledge. http://dx.doi.org/10.4324/9780203411940

Olatubara, C. O. (2003). The participation of women in residential location decision-making in Ibadan, Nigeria. Journal of the NITP, XVI(1), 19-33.

Onibokun, P. (1983). Issues in Nigeria Housing (pp. 45-65). NISER, Ibadan.

Onibokun, G. A. (1985). Housing in Nigeria: (A Book of Readings) (pp. 65-83). NISER, Ibadan.

Pascall, G. (1997). Social Policy: A New Feminist Analysis. London: Routledge

Peterson, R., Wekerle, G. R., \& Morley, D. (1978). Women and Environments: An Overview of an Emerging Field. Environment and Behaviour, 10(4), 511-534. http://dx.doi.org/10.1177/001391657801000403

Robertson, C. (1984). Shanney the Same Bowl: A Socio-economic History of Women and Class in Accra, Ghana. Blymindon: Indiana University Press.

Seager, J. (1992). Women Deserve Spatial Consideration or Geography like no one ever learned in School. In K. Cheris \& S. Dale (Eds.), The Knowledge Explosion: Generations of Feminist Scholarship. London Athene series, Teachers College.

Short, J. P. (1996). The Urban Order: An Introduction to Cities, Culture and Power. USA: Blackwell.

UNCHS. (1996). An Urbanizing World: Global Report on Human Settlements. United Nations Centre for Human Settlements (HABITAT) Oxford University Press.

Weisman, L. K. (1992). Designing differences: Women and Architecture. In C. Kramarae \& D. Spender (Eds.), The knowledge Explosion: Generations of Feminist Scholarship (pp. 310-321). London: Athene Series, Teachers College Press.

Wekerle, G., Peterson, R., \& Morley, D. (1980). New Space for Women. Boulder, C.O. Westeview Press.

Williams, S. (1994). The Oxfam Gender Training Manual. UK: Oxfam. 
Woods, R. (1994). Introduction. In R. Gilroy \& R. Woods (Eds.), Housing women (pp. 1-10), London: Routledge.

Woolley, T. (1994). Innovative Housing in the UK and Europe. In R. Gilroy \& R. Woods (Eds.), Housing Women (pp. 247-259). London: Routledge.

Appendix 1. Shows the Mean, the Standard Deviation and the analysis of variance (ANOVA) test of women satisfaction with different aspects of housing in Ibadan

\begin{tabular}{|c|c|c|c|c|c|c|c|c|c|c|}
\hline \multirow[t]{2}{*}{ Aspects of Housing } & \multicolumn{2}{|c|}{$\begin{array}{l}\text { High (core) } \\
\text { Density } \\
\text { Residential } \\
\text { Area }\end{array}$} & \multicolumn{2}{|c|}{$\begin{array}{l}\text { High Density } \\
\text { Residential } \\
\text { Area }\end{array}$} & \multicolumn{2}{|c|}{$\begin{array}{l}\text { Medium } \\
\text { Density } \\
\text { Residential } \\
\text { Area }\end{array}$} & \multicolumn{2}{|c|}{$\begin{array}{l}\text { Low Density } \\
\text { Residential } \\
\text { Area }\end{array}$} & \multicolumn{2}{|c|}{$\begin{array}{l}\text { Analysis of } \\
\text { variance } \\
\text { (ANOVA) result }\end{array}$} \\
\hline & Mean & $\begin{array}{l}\text { Std. } \\
\text { Dev. }\end{array}$ & Mean & $\begin{array}{l}\text { Std. } \\
\text { Dev. }\end{array}$ & Mean & $\begin{array}{l}\text { Std. } \\
\text { Dev. }\end{array}$ & Mean & $\begin{array}{l}\text { Std. } \\
\text { Dev. }\end{array}$ & F-value & Sig. \\
\hline Kitchen & 2.65 & .744 & 2.74 & .660 & 2.92 & .689 & 3.10 & .641 & $3.254 *$ & .021 \\
\hline Balcony/Corridor/Verandah & 2.63 & .704 & 2.83 & .700 & 2.98 & .715 & 3.06 & .676 & $16.200 * *$ & .000 \\
\hline Backyard & 2.74 & .632 & 2.85 & .639 & 2.93 & .737 & 3.12 & .816 & $3.020^{*}$ & .029 \\
\hline Bathroom & 2.54 & .677 & 2.80 & .700 & 2.98 & .672 & 3.16 & .671 & $9.954 * *$ & .000 \\
\hline Toilet & 2.56 & .745 & 2.79 & .681 & 2.93 & .695 & 3.10 & .671 & $6.831 * *$ & .000 \\
\hline Ventilation & 2.67 & .682 & 2.95 & .553 & 3.00 & .689 & 3.27 & .532 & $13.677 * *$ & .000 \\
\hline Drinking Water Supply & 2.49 & .719 & 2.59 & .706 & 2.53 & .843 & 3.04 & .631 & $6.983 * *$ & .000 \\
\hline Washing Water Supply & 2.67 & .627 & 2.71 & .661 & 2.77 & .816 & 3.06 & .644 & $3.141^{*}$ & .025 \\
\hline Noise & 2.37 & .658 & 2.54 & .774 & 2.66 & .800 & 3.12 & .739 & $16.812 * *$ & .000 \\
\hline Pollution & 2.42 & .736 & 2.63 & .727 & 2.87 & .665 & 3.24 & .681 & $19.277 * *$ & .000 \\
\hline Safety & 2.66 & .689 & 2.77 & 690 & 2.89 & .685 & 3.22 & .503 & $6.748 * *$ & .000 \\
\hline Power Supply & 2.15 & .741 & 2.37 & .823 & 2.32 & .892 & 2.78 & .832 & $12.271 * *$ & .000 \\
\hline Courtyard & 2.57 & .833 & 2.79 & .681 & 2.79 & .870 & 3.02 & .927 & $9.555^{* *}$ & .000 \\
\hline All the Variables combined & 2.55 & .707 & 2.72 & 692 & 2.81 & .751 & 3.10 & .690 & $16.485 * *$ & .000 \\
\hline
\end{tabular}

